\title{
The Declamatory Tradition of Normative Inquiry: Towards an Aesthetic History of Legal and Political Thought
}

\author{
Maksymilian Del Mar ${ }^{\#}$
}

\begin{abstract}
This paper offers an example of what may be called 'an aesthetic history of legal and political thought'. Such a task engages in theorising historically the features of aesthetic traditions that enable and further normative inquiry, i.e. an exploration of the norms and values that might contribute to the good life and the common good. The three features offered in this paper as useful to identifying such aesthetic traditions are: communality and interactivity; experimentalism; and exemplarity. The paper shows how each of these features is present, in particular ways, in one specific aesthetic tradition, namely the declamatory tradition. Tracing the declamatory tradition back to Ancient Rome, and examining its influence in the English Renaissance, especially in Sir Thomas More's response to Lucian's declamatory thema, Tyrannicide, the paper argues that the particular ways in which declamatory practice combines the above three features enables those engaged in it to pursue normative inquiry. The paper argues that the integration of these three features is especially visible in one aspect of declamatory practice, namely the introduction and exchange of colores, i.e. changes in the narrative, introduced by declaimers and their audiences, which shed light on the possible motivation of a character, and thereby also invited shifts in affective allegiance and evaluative perspective. The paper argues that it is in large part through such introduction and exchange of colores that the declamatory tradition enables and furthers normative inquiry, and thus also offers a good reason for including the declamatory tradition in 'an aesthetic history of legal and political thought'.
\end{abstract}

\section{Keywords}

Declamation; Seneca; Thomas More; interaction; experimentalism; exemplarity

\section{Introduction}

An important topic, surely, for any journal investigating the philosophy of law and politics is the relationship between, on the one hand, legal and political thought, and on the other hand, aesthetics. There are many ways in which this can be - and of course has been - done. One is to examine the aesthetic features of what are conventionally treated as texts in the tradition of legal and political thought, e.g. to explore the dramatic qualities of Plato's dialogues, or the role of rhetorical devices in Hobbes, or the use of 'images' in Locke. ${ }^{1}$ Another way is to look at aesthetic practices themselves, i.e. roughly, practices of making that are reflexive about their

\footnotetext{
\# Professor of Legal Theory, Queen Mary University of London. Some of the material in this paper was presented at a conference on 'Law and Poetics in Early Modern England and Beyond', at the University of Cambridge, 2-4 July 2018. I am especially grateful for comments and questions from Subha Mukherji, Rachel Holmes, Kathy Eden, Andrew Zurcher, Sebastian Sobecki, Julie Stone-Peters, Gary Watt, Lorna Hutson, Bernadette Meyler, and Richard Sherwin. A number of friends and colleagues have read earlier drafts or simply encouraging me in this endeavour. I thank in particular Alexandra Braun, Roger Cotterrell, Karen Cunningham, Joanne Paul, Paul du Plessis, Peter Mack, Simon Stern, and Quentin Skinner. I also thank the journal's anonymous reader of an earlier draft of this paper.

${ }^{1}$ See e.g. La Caze 2002.
} 
own form, including, paradigmatically, varieties of literature, drama, the visual arts and film, sculpture, architecture, and other arts, and to attempt to articulate how they draw on form, in particular ways at particular times and places, to explore legal and political issues, and often to challenge or transform legal and political practices.

In broad terms, the approach taken in this paper is the second. However, I am especially interested in aesthetic practices that are not conventionally or paradigmatically thought of as 'aesthetic', often because they are characterised or catalogued in other ways, for instance as pedagogical practices. Further, the practices I am interested in are rarely under the radar of those interested in the history of legal and political thought - in part because they are not systematic, philosophical treatments, and in part because they are not merely or even mainly texts but rather practices, sometimes with some textual element.

In this paper, I offer three features that may help us identify those 'aesthetic traditions' and trace their influence over time. I am not offering these as universal or timeless categories of the 'aesthetic'. Indeed, in employing the term 'aesthetic' I do no mean to refer to any specific canon of philosophical reflection on the arts, e.g. either the German canon, with Baumgarten, Kant and Hegel, or the American pragmatist canon, as with say Dewey. ${ }^{2}$ Rather, I offer them tentatively as ways of exploring and historicising the more particular features of aesthetic traditions. It may well be that we can discern the presence of these three features across a whole range of aesthetic traditions, but it is also likely that there are other features that are equally important and that will enable us to identify other aesthetic traditions.

The three features are: first, communality and interactivity; second, experimentalism; and third, exemplarity.

The first of these - communality and interactivity - puts the spotlight on the forms and processes of community-making, including different ways of bonding, sharing and participating together, as well as on interactive dynamics, whether these be short and intense or extended over time. Important always to communality and interactivity is the politics and ethics of inclusion and exclusion, and thus one must pay attention to who is allowed to participate and how, and how epistemic power and privilege are distributed across the group, as well as how members of that community project outwards to others not included in the group.

The second feature is that of experimentalism. Here, the focus is on the different ways in which we create space and time for thought, such that we can try out alternatives and possibilities without the usual pressures and burdens imposed on by our epistemic norms and commitments. Thus, the attention in this feature is on the variety of means we have for creating for ourselves and signalling to others that we have created little niches, pockets or enclaves for non-committal, tentative modes of thought. Experimentalism can manifest itself in different ways, for instance, through comic forms. The absurd, the implausible, the hyperbolic, the caricatured and related forms (both in language and visually) can often work well as cognitive and embodied signalling of the relaxation of otherwise common epistemic constraints.

The third and final feature is exemplarity. This feature picks up on a range of different forms - especially forms of language and narrative composition - that occupy a middle space between the particular and the general. They embody sufficient particular, concrete detail to involve us and connect to our emotions and bodies, while at the same time being incomplete and including some level of generalisation and abstraction, thereby pointing beyond themselves and calling on us to do things with them. These are highly suggestive forms, which are also often short and under-specified, or may deploy or point to certain generic or stock patterns, characters or phrases. Processing exemplary forms requires us to be active - again, to think

\footnotetext{
${ }^{2}$ I acknowledge that there may well be echoes of the three features I identify in the canons of philosophical aesthetics. To trace and discuss those echoes is, however, outside the scope of this paper.
} 
beyond what is immediately available. Examples would include anything from proverbs to parables, including anecdotes, fables or the very idea of a 'case'.

In this paper, I draw on these three features in order to explore, in more particular detail, one specific aesthetic tradition, namely the declamatory tradition. There are other aesthetic traditions I could have examined, e.g. the disputational or dialogical tradition, as found in certain strands of poetry and drama; ${ }^{3}$ or the counterfactual tradition, including in history, literature and film. ${ }^{4}$ But the declamatory tradition is a good start, in part because it has also been so neglected, both by scholars in legal and political philosophy, and by historians of aesthetic practices.

How does the declamatory tradition connect to legal and political thought? Here is where I argue that the presence of the three features noted above in the declamatory tradition enables 'normative inquiry', i.e. an exploration of the norms and values that might contribute to the good life and the common good. In other words, we can better see the connections of the declamatory tradition to legal and political thought if we approach the declamatory tradition via the above three features. It is precisely by examining the particular shape given to communality and interactivity, experimentalism and exemplarity in the declamatory tradition that we are able to see how it, again in particular ways, enables the pursuit of normative inquiry, and thus also why it belongs to any 'aesthetic history of legal and political thought'.

Of course, in an article of this length, I am constrained in how much of the declamatory tradition I can cover. The tradition is a rich and complex one, and with a long history across a range of different cultures. Given those limitations, I focus only on two broad historical contexts, and even then of course inadequately: first, I offer an account of the precursors and beginnings of the declamatory tradition in Ancient Rome; and second, I examine the declamatory tradition in the English Renaissance, as illustrated by Erasmus's and (especially) Thomas More's reply to Lucian's declamation, Tyrannicide.

As shall become clear, this paper places special emphasis on the importance of colores in the declamatory tradition, this being an aspect that is of central important to both historical contexts examined here. A color, or colour, was an alteration of narrative circumstance, introduced by a declaimer and members of the audience, that shed light on the possible motivations of a character, and in doing so, invited a shift in affective allegiance and evaluative perspective. The introduction and exchange of colores, or colour, by a declaimer and their audience, is a critical part of the declamatory tradition. It also offers an especially striking illustration of the integration of the three features mentioned above. In other words, the practice of introducing and exchanging colores by declaimers and their audiences is argued to be a paradigmatic case, within the declamatory tradition, of the integration of communality and interactivity, experimentalism and exemplarity. Further, this introduction and exchange of colores, precisely because of its combination of the above three features, enables and furthers normative inquiry. It is, in large part, because of the introduction and exchange of colores that declamatory tradition can offer us an example of an aesthetic mode of inquiry into the good life and the common good. It is also for that reason that it deserves its place in the 'aesthetic history of legal and political thought'.

\footnotetext{
${ }^{3}$ See Enders 1992.

${ }^{4}$ See Gallagher 2018.
} 


\section{The Declamatory Tradition: Ancient Precursors and Beginnings}

\section{IA. The Three Features of the Declamatory Tradition}

Declamatory practice has a rich and complex history. There were declamatory practices already amongst the Greek sophists in $5^{\text {th }}$ century BCE, ${ }^{5}$ but it may be that we need to seek the origins of the declamatory genre in the birth of 'comic drama', said to have been 'invented at Megara, in the early $6^{\text {th }}$ century BCE, after a democratic evolution'. ${ }^{6}$ Perhaps the earliest of these comic forms was the 'mime' or mimos, which was 'a short, dramatic sketch, sometimes with two or three speakers (or more), and sometimes just a single speaker in a dramatic monologue'. ${ }^{7}$ It is important that these mimes often dealt with 'characters from daily life' in addition to myths, and thus included characters such as 'women visiting a temple, truant schoolboys, athletes, rustics, old men, old women, sausage-sellers, crafty slaves, and so on' ${ }^{8}$ They were sometimes 'pornographic or obscene' and 'often...farcical'. ' Jeffrey Walker provides the following account of their performance:

It [the mime] began as popular entertainment, performed on makeshift wooden stages - a small platform with a backdrop and a door - at festivals or in marketplaces. The actors generally wore masks and padded costumes, featuring (for the male characters) a protruding paunch and rump, short shirt (chiton), tights, and a large dangling phallus. ${ }^{10}$

What might seem like a rather fantastic and indulgent practice had deep political resonances in the period. As Walker explains, 'Mime originates from within, and is an expression of the political, social and intellectual turbulence of the Greek world from the $7^{\text {th }}$ to $5^{\text {th }}$ centuries, which saw the displacement of the traditional ruling classes, and the ideologies and mythologies that supported them'. ${ }^{11}$ One of the most famous figures in the development of the mime was Sophron of Syracuse, a $5^{\text {th }}$ century BCE Sicilian poet. Sophron composed his mimes in prose, and they all featured common people in commonplace situations. ${ }^{12}$ Significantly for present purposes, it was said about Sophron that the 'charm' of his mimes 'lay in its sudden shifts "contrary to expectation". ${ }^{13}$ Indeed, Walker has claimed that Sophron's mimes were key to the development of the Greek sophistic declamations:

My point is that, in the mimes of Sophron, we can find several key characteristics of the sophistic declamation, as it emerges with Gorgias: a dramatized character embedded in a particular set of circumstances, arguing his or her case; everyday, ephemeral speech-genres, including the practical oration, represented not in verse but in prose, or 'rhythmic' prose; and a comic playfulness with argument, in which the weaker may

\footnotetext{
${ }^{5}$ For the Greek practice, see Russell 1983. Russell famously invented the city of Sophistopolis (chapter 2 ), the fictional city of the fictional cases of the Greek declamations. See also Amato, Citti and Huelsenbeck 2015.

${ }^{6}$ Walker 2005, p. 201. The Megarian democracy was established in 581 BCE after the overthrow of the tyrant Theagenes and lasted till 424 BCE.

${ }^{7}$ Ibid. p. 200.

${ }^{8}$ Ibid.

${ }^{9}$ Ibid.

${ }^{10}$ Ibid.

${ }^{11}$ Ibid. p. 203.

${ }^{12}$ Ibid. p. 204.

${ }^{13}$ Ibid., citing Demetrios, On Style.
} 
become the stronger, or the worse better, or 'low' characters can have their say, or counter-intuitive, counter-commonsensical, or counter-traditional ideas can be entertained. ${ }^{14}$

Mimes, then, were a highly generative genre, influencing Greek sophistic practices, including the development of the declamations, as well as the birth of fully-fledged comic drama familiar to us from the works of Aristophanes - and then into the New Comedy of Menander. ${ }^{15}$

Mimes may not be the only precursor, of course. Another possibility is the invention of the 'paradoxical encomium', or 'a species of rhetorical jest...which involves the prise of unworthy, unexpected, or trifling objects, such as the praise of lying or envy or of the gout or of pots and pebbles'. ${ }^{16}$ The earliest traces of these practices appear in the $5^{\text {th }}$ century BCE, including amongst some of the most famous sophists of the period (e.g. Georgias and Isocrates). Indeed, there is even 'evidence to indicate that paradoxical encomia were set as exercises in the ancient schools of rhetoric', contributing to the centrality of the 'unusual and the unexpected' in sophistic training in general. ${ }^{17}$ There is, in these praises of the gnat, the parrot and hair, or of fleas, lice and bedbugs, the sense of a challenge to even the most selfconfident of orators, and it is no wonder that the genre of the paradoxical encomium was a popular one amongst the playful humanism of the Renaissance - with compositions in praise of everything from the fly to the elephant. ${ }^{18}$

The great flowering of comic and paradoxical genres of the $6^{\text {th }}$ and $5^{\text {th }}$ centuries BCE in Greece, and, as we shall see, their subsequent revival in the Renaissance, provide us with some clues as to the flavour and character of the declamations. The declamations, like the mimes and the paradoxical encomia, delight in both implausibility, hyperbole and difficulty. Also like them, declamations push cognition to the limits of the conceivable, the persuadable, or the reasonable. All three also contain much pleasure, e.g. in their twists and turns of perspective, and in their constant frustration of expectations. The rhetorical challenge in the paradoxical encomia, for instance, was to transform the uncommon into common. The art of the mimes, we are told, consisted in introducing sudden shifts of expectation. Arguably, the mimes also sought to excavate points of view and lines of argument that might otherwise be hidden from view (again, bringing the uncommon into common view). Further, although both the mimes and the paradoxical encomia are comic forms, they are in many ways serious undertakings and certainly have serious political echoes. The very act of speaking in the name of a socially marginalised character - giving them voice where they had none - or of praising an object that is otherwise taken for granted and denigrated, is a subversive political act.

As with the distant precursors of the declamations, so with the Roman declamations themselves: they have a complex history in their own right, going through changes in style, and being entangled in the changing political landscape. Neil Rhodes puts it as follows:

The political shift from Republic to Empire was accompanied by a change of style in the declamation, along with a perceived degeneration in the arts of eloquence in general. Starting out as a training for the legal profession and political life, and informed by Cicero's ideal of the civic duties of the orator, under the Empire the declamations became quasi-theatrical entertainments with sleazier, more extravagant and sensational

\footnotetext{
${ }^{14}$ Ibid.

${ }^{15}$ Ibid. p. 201. The comic tradition is itself vital for an aesthetic history of legal and political thought, see e.g. recently, Fletcher 2016.

${ }^{16}$ Miller 1956, p. 145.

${ }^{17}$ Ibid. p. 147.

${ }^{18}$ Ibid. p. 152. As was the case often, Erasmus was a key figure in the popularisation of this classical genre.
} 
subjects. While Cicero had declaimed in private as a way of keeping his speaking skills up to scratch, under Augustus the declamation developed alongside poetry recitation as a popular form of verbal display, attended by large audiences and subject to applause, derision, and critical comment. ${ }^{19}$

The declamations have often been a source of derision and heavy critique, but it must be remembered that at least some of those critical comments were made in the context of the later declamations. ${ }^{20}$ The declamations that I shall focus on describing here are those of Seneca the Elder in the first century CE, around the time or just after Cicero's death. ${ }^{21}$

We must also remember that the declamations were advanced exercises for students who had been, by the time they attempted them, already exposed to rhetorical training. Originating probably in the Hellenistic era $\left(3^{\text {rd }}\right.$ to $1^{\text {st }}$ century BCE), rhetorical schools began to introduce progymnasmata. These were around a dozen or so exercises for writing and speaking instruction, which, by the $1^{\text {st }}$ century BCE, became standard curriculum for Greek and Roman rhetorical schools. ${ }^{22}$ The progymnasmata exercises included: fables, tales, sayings, proverbs, the encomium, invective, comparison, characterisation and description. For instance, students were tasked with paraphrasing or amplifying a fable, or (in a form called the chreia) elaborating on the sayings or doings attributed to a famous person. These were already quite complex tasks - for example, the chreia exercise involved eight stages, from writing a panegyric on the person in question, offering proofs in favour of the saying attributed to them, to exhorting the audience to emulate the person involved. ${ }^{23}$ By the time the student came to the declamations, then, he for the school was for Roman boys and young Roman men - was already familiar with a range of exemplary forms that he had been experimenting with in the company of others. These were the nascent or emerging combinations of the three features (communality and interactivity; experimentalism; and exemplarity) that were then enhanced and developed in the declamations.

The declamations themselves came in two varieties: the suasoriae (speeches on behalf of some figure, typically a politician, in some set of circumstances, e.g. Cicero in his final hours) and the controversiae. It is the latter that I am interested in here.

The form of the controversiae was that they would they would (usually) first articulate a legal principle or more than one (e.g. 1: in whatever place someone is struck by lightning, they ought to be buried there, and 2: the body of a tyrant must be cast away outside the boundaries of the town), and then offer a 'thema', or precisely a hypothetical fact or hypothetical narrative (e.g. a tyrant is struck by lightning in the town square). The controversiae thus often pitted two legal principles against each other (in this example, burying someone where they are struck by lightning versus not burying a tyrant within the bounds of the town), or articulated hypothetical facts that put pressure on the scope and meaning of a single legal principle.

\footnotetext{
${ }^{19}$ See Rhodes 2008, p. 93.

${ }^{20}$ Thus, already by the time of the death of Quintilian (100 AD), the declamations had already somewhat changed character, with the Empire already being almost 70 years old in $100 \mathrm{AD}$. As Cleve Wiese puts it, in Quintilian's age 'the declamation exercises were beginning to take on some of the flamboyant characteristics that would reach their apogee in the rhetoric schools of the Second Sophistic period': Wiese 2016, p. 143. Quintilian was certainly critical of some elements of the declamations, though he also does qualify his criticism. There is no doubt, however, that much criticism was made of the experimentalism of the declamations, especially in the Second Sophistic (e.g. by Tacitus).

${ }^{21}$ For more historical context on Seneca and what practices he described, and the functions and effect of his text, see Winterbottom 1974. For a discussion on Quintilian's declamations, as well as Quintilian's view of declamatory practice, see Winterbottom 2019.

${ }^{22}$ See Fleming 2003, p. 109-110.

${ }^{23}$ Ibid. p. 111.
} 
The format of the declamations in the classroom was roughly as follows:

...the rhetor [the teacher] would present a new case and provide some introductory commentary [sometimes included in declamatory texts as the 'sermones'] on the status of the issues involved, on the propria (or unique) as well as communia (or general) arguments, and on how these all might be arranged and presented... Following this guided introduction, students would first compose and then read their own declamations to the teacher; and after careful correction, they would commit these speeches to memory. Once rehearsed, students would deliver their oration to their schoolmates who were free to respond directly to each oration. The public nature of the classroom was further enhanced by the occasional presence of adult visitors who were also free to comment... Pupils...could count on a lively response from a very real audience who would not hesitate to applaud or even hiss. As a finale for these activities, the rhetor would, in most cases, deliver his version of the declamation and so provide another model against which students could measure their own efforts. ${ }^{24}$

To this we need to add that the performance in the classroom involved speeches made on behalf of each side, which would then be followed by feedback from the audience (sometimes extending to interruptions during the performance), ${ }^{25}$ with alternatives and improvements offered on the speeches already given. Further, it is also crucial that students would write and perform in the voice of a fictional persona (wearing their mask, as it were), namely a character in the thema. Famously, the students would not shy away from describing the often violent or otherwise explicit facts in quite some detail. In addition, the performances were said to be emotionally charged and very expressive physically. Declaimers were expected to really inhabit the persona of the thema. Thus, for example, with respect to emotion, Quintilian says: 'We play the part of an orphan, a shipwrecked man, or someone in jeopardy. What is the point of taking on these roles if we do not also assume the emotional?'. ${ }^{26}$

This brief account already attests to how the declamations exhibit the three features of the declamatory tradition mentioned above. They are clearly communal and interactive. The groups of boys that had already formed communities in the schools teaching progymnasmata now came together to perform suasoriae and controversiae together. Further, we know that the young men who graduated from these exercises continued to sometimes declaim together as adults. ${ }^{27}$ The communities in question were exclusive, with the boys of elite families participating, but it was also not impossible for a boy from the provinces to participate (Seneca the Elder, after all, came from Spain) and it was also not that unusual for a rhetor to be a former slave. $^{28}$

The interactive dynamics here are especially important. As noted above, declamatory audiences were not passive: they were vocal in approval or disapproval, they interrupted, and they offered alternatives, improvements and criticisms following the initial speeches. Characterising the declamations as examples of 'controversial thinking' ${ }^{29}$ Michael Mendelson speaks of how they trained a 'willingness to place opposing ideas, issues, contexts and

\footnotetext{
${ }^{24}$ Mendelson 1994, p. 95.

${ }^{25}$ Bloomer 2015, p. 118.

${ }^{26}$ Quintilian 2002 [95 CE], para 6.2.36.

${ }^{27}$ See Seneca 1974, 2.4.12-4. See also Brightbill 2015, who says (at p. 3) 'declamation continued to be practiced by adult elites, and performances were even held in the court of the Emperor Augustus'.

${ }^{28}$ See Bloomer 2015, p. 111.

${ }^{29}$ See Sloane 1985.
} 
narratives in juxtaposition'. ${ }^{30}$ Indeed, the interactive dynamics were such as to maximise this juxtaposition of alternative and conflicting arguments. Mendelson adds:

...the process of invention in a controversia is dialogical, as all the students dealing with the same declamatory case react to one another in a give-and-take of actual rather than hypothetical (or monologically produced) perspectives. In the process of listening to the interactive banter of the class, the student declaimer is alerted to the limits of the individual imagination, and so should begin to cultivate an appreciation for the variety of responses potentially raised by a particular case. At the same time, the student rhetor, guided by the teacher, will come to recognise that each new position advanced must alter in some way - rather than simply duplicate - an initial idea, so that each new turn in the discussion of alternatives yields, by its very nature, that which was not there before. The debate of the classroom, therefore, provides a dynamic favourable for invention, a dynamic that invariably expands the range and enhances the subtlety of the student rhetor's grasp of arguments on either side. In the careful exercise of controversial thinking, then, the student is prompted not only to develop a full store of working concepts from which to build an effective declamation but also to recognise that rhetoric abhors simply casuistry and instead insists that invention be informed by the interactive play of multiple voices, in contrares partes, that make up the drama of any actual controversy. ${ }^{31}$

In addition to being communal and interactive, the declamatory exercises were also clearly experimental. Indeed, this is perhaps their most commonly noted and controversial aspect. There are two aspects of this experimentalism that were discussed then, as well as since then. The first was that some, if not many, of the laws that formed the subject of the themata were fictional - for instance, correlating more to a long-past Greek world rather than to a contemporary Roman one. Not everyone agrees as to just how closely related the laws were to contemporary Roman practice, but the consensus now seems to be that the fictionality of the laws was not an obstacle to the exercises serving an important pedagogical function, including as preparation for advocacy in the Roman courts. ${ }^{32}$ Indeed, from the perspective of this paper, the distance of the laws from practice aided in creating an atmosphere of experimentalism. As Martin Bloomer put it, 'had they been real Roman laws, the discourse about them would have been severely limited, and part of the point of declamation was to get teenage boys to speak freely'. ${ }^{33}$

It is, however, the second aspect of the experimentalism of the declamations that has been the more common target of derision and criticism - and that is the fantastic and highly unrealistic facts of the declamatory themata. Notoriously, for example, Petronius, writing in the late $1^{\text {st }}$ century CE, had written in the Satyricon:

\footnotetext{
${ }^{30}$ Mendelson 1994, p. 97. Mendelson also cites Quintilian (2002, at para 6.4.14): 'The process of scrutinising such cases amounts to circling around an argument, exploring multiple, often contradictory points of view, all of which, when seen in isolation, would in some way be limited. The student is consequently building a composite narrative of the circumstances, a narrative that attempts to respond to the situation in all its contextual richness... the many conflicting arguments that attend to a case, the multiplex ratio disputandi.'

${ }^{31}$ Mendelson 1994, p. 98.

${ }^{32}$ For this debate in general, see e.g. Bonner 1949; Crook 1995; Parks 1946; and, more recently, Dinter, Geurin and Martinho 2016.

${ }^{33}$ Bloomer 2015, p. 137.
} 
Here's why I think that young people are becoming dolts at school: they don't hear about or witness anything that we see in ordinary life, just pirates standing on the shore in chains, tyrants composing edicts that order suns to cut off their fathers' heads, and oracular responses to plagues that mandate the sacrifice of three or more virgins. ${ }^{34}$

Quintilian, too, though not so extravagantly, had criticised the fantastic implausibility of the declamatory themata. He called for them to 'not be such as to seem foolish and laughable to the eye of an intelligible observer', though he also characteristically qualified this statement by saying that 'if we must make concession, let us allow the declaimer to gorge himself occasionally'. ${ }^{35}$ Further, Quintilian recognised the function of the themata as piquing and maintaining the interest of the younger declaimers. ${ }^{36}$ The approach to this aspect of the declamations in the $20^{\text {th }}$ century seems to be different: it is to ask, what was the pedagogical value of the themata being so fantastic? This may have been a trend begun by Frederick Bonner, writing in 1949:

The answer to this question [as to why the facts of the themata were so fantastic] seems hardly to have been made, and it may be suggested that these are test-cases in more senses than one. They not only test the validity of a law by positing more and more extreme circumstances - e.g. "children must support (or obey) their parents" - what if the parents are manifestly undeserving, ungrateful, indeed criminal, the children marked by every known virtue, models of piety, saviour indeed of their country? Is the law still applicable? They also test the powers of the declaimer; the harder the case is, the more removed from the circumstances of everyday life, where there is nearly always something to be said on both sides, the better the declaimer needs to be to cope successfully with it. If he can produce a reasonably good defence with heaven and earth against him, he should, theoretically, be able to tackle law-court cases with greater ease. $^{37}$

The experimentalism of the themata was evident not only in the characters that were prominent in them - for instance, involving pirates and prostitutes - but also in the kinds of events that occurred. And, in this respect, the extremes pushed were not merely those of cultural or factual plausibility; they were also emotional. As Bloomer has noted, the events described in the declamations were often the worst possible scenarios of what could happen to a family - or to a father, a mother, an uncle, a stepfather or stepmother, a brother, a son, or a daughter. For instance: 'A daughter is raped; a son is disobedient and ungrateful; a father is so harsh and unfeeling that he disinherits his own son'. ${ }^{38}$ They were often scenarios of familial crisis - the stuff of nightmares. As Joy Connolly has written, in the declamations 'anger, grief, pain and love are expressed in extravagant terms on almost every page' and 'the physical effects of suffering are portrayed in close detail'. ${ }^{39}$ 'These texts', Connolly adds, 'draw us to concentrate on moments where speakers dissolve into tears and cries of anguish, where they experience the somatic limits of experience'. ${ }^{40}$ In many respects, Connolly argues, the declamations can be understood as 'experiments in suffering and its representation'. ${ }^{41}$

\footnotetext{
${ }^{34}$ Quoted in Corbeill 2010, p. 74.

${ }^{35}$ Quintilian 2002, para 11.10.6.

${ }^{36}$ For discussion, see Bloomer 2011.

${ }^{37}$ Bonner 1949, p. 83.

${ }^{38}$ Bloomer 2010, p. 305.

${ }^{39}$ Connolly 2016, p. 200.

${ }^{40}$ Ibid. p. 208.

${ }^{41}$ Ibid. p. 192.
} 
The experimentalism of the declamations extended to the performance. As above, declaimers took on a fictional persona of a character in the thema, and performed in their voice, with their imagined emotions and gestures. This was widely recognised to have been valuable pedagogically. Many commentators have made the point that having to speak in the voice of these characters, who were often socially marginalised and in inferior social positions to the declaimers themselves, encouraged the declaimers to become more aware of persons who were much less fortunate than they were. ${ }^{42}$ The declamations, says Bloomer, 'trained a young Roman in a sympathy of viewpoint, emotions, motivations and speech' that, Bloomer adds, 'he would need in treating his future clients' ${ }^{43}$ Further, this 'transgression of voices', as Bloomer has called it, was not only fun, no doubt involving much humour (with comedy, too, depending 'on the disjunctive of person and speech type'), but also had a strong political resonance. ${ }^{44}$ In this respect, Roman declamation had again much in common with Roman comedy:

Generational and social strife may be said to be surfacing, but, more concretely, Roman schoolboys were performing a sort of role-playing that did not directly advocate the dominant ideology. Indeed, declamation reads, like much of New Comedy, as a confrontation with paternal severity. With father off the stage, in temporary exile, at sea, or away from school, the son seizes his liberty of speech and imagined action. Law, the embodiment of the patres' severity, does not rule adolescent speech but is instead elaborated, embellished, its unyielding verbal texture resisted. Thus arises a speech not bound by law, not answerable to the single judge, to the older judge, or even exclusively to the freedom schoolmaster or servile pedagogue but, to a degree, to peers. ${ }^{45}$

There were, then, subversive aspects to the experimentalism of both the genre and the performances of the declamations. Of course, we should not exaggerate too much: the exercises were also shot through with conventionalism in all kinds of ways. Indeed, some commentators have suggested that 'the sensational nature of the themes actually worked to reinforce confidence in the sufficiency of custom and tradition', for they showed that even 'the most startling, novel or extravagant circumstances could be dealt with by applying the tradition wisdom of the mos maiorum' ${ }^{46}$ A balance no doubt needs to be struck: the practice combined reference to certain conventional norms and values together with questioning them, and thus generating alternatives and possibilities, exploring their relevance for contemporary Rome. As Bloomer puts it, 'Cultural and social categories are here being defined and contested' at the same time, and all in this 'liminal site, the school with its fantasies of adult speech and life'. ${ }^{47}$

In addition to being communal and interactive, and clearly experimental, the declamations were also exemplary. The hypothetical facts of declamatory themata, as described by Seneca the Elder, were short and suggestive. They occupied a middle space between the particular and the general, being sufficiently particular to place one within a situation, but sufficiently under-specified so as to not only allow but in fact require much further inferential work. Declaimers, in other words, had to work to fill in the gaps and expand the narrative into a coherent and persuasive speech.

\footnotetext{
${ }^{42}$ See Bernstein 2013.

${ }^{43}$ Bloomer 2015, p. 139. See also Friend 1999.

${ }^{44}$ Bloomer 2015, p. 139.

${ }^{45}$ Ibid. pp. 138-9.

${ }^{46}$ See Kaster 2001, p. 325. See also Bernstein 2013; and Gunderson 2003.

${ }^{47}$ Bloomer 2015, pp. 110-111.
} 


\section{IB. Colores}

One of the main ways in which the declaimers did this inferential work was via the invention and introduction of colores. The term and concept of colour has its own complex history. ${ }^{48}$ Today, we sometimes speak of 'colourful characters' or 'colourful language', and we speak, in a related way, of something 'colouring our judgement'. There are also more technical uses of colour, e.g. developing in the early fourteenth century, colour was a technical term of pleading in the early modern common law (given the importance of this for the Renaissance, I return to it below), and colours were sometimes understood to be commonplaces (this, too, was a Renaissance echo: as, for instance, in Sir Francis Bacon's The Colours of Good and Evil). ${ }^{49}$ What is important for present purposes is that we do not restrict the sense of colour to the literary quality of one's language (the more expressive and vivid use of language) ${ }^{50}$ and instead embrace the broader sense of colour, which involves introducing a change in the narrative, which either directly or indirectly characterises the motivation or intention of one of the parties in the narrative, and which affects or can affect the affective allegiance of the reader or audience to a character or to the action of a certain character, and thus ultimately also their evaluation of that action or character. It is this broader sense of colour is what I am interested in here, and also this broader sense which was clearly deployed by the declaimers. ${ }^{51}$ It is also this broader sense of colores which I am suggesting enables and furthers normative inquiry, and that may thus be thought of as a mode of legal and political reasoning. ${ }^{52}$

The introduction of colores could not, of course, contradict the thema. However, since themata were so thin in their facts (i.e. under-specified), they left - indeed, this was their point - a great deal of room for such invention. Thus, in many respects, the very art of declaiming consisted in inventing colores that could and would affect the emotions and ultimately also the judgment of the audience about the character in question. At one level, the point certainly was to move and persuade the audience; on the other hand, everyone involved in the exercise, though engaged in the declamation (especially if it was a good one!) was also aware of the fictionality of the exercise. Hence also the practice of exchanging colores - of having multiple declaimers introduce colores while presenting different personas in the thema, and also inviting colores from the audience and the rhetor himself. One could say here that the exemplarity both enables and calls for experimentalism, and lends itself to being played with communally and interactively. The argument here, then, is that the declamations, and especially through the unique and potent mix of communality and interactivity, experimentation and exemplarity in

\footnotetext{
${ }^{48}$ See also Roller 1997.

${ }^{49}$ Bacon 1597. As Lisa Jardine notes, the colours in Bacon are understood to be 'popularly accepted judgments of relative worth': Jardine 1974, p. 222.

${ }^{50}$ A related use is that of 'purple prose': see Lysyk 1998.

${ }^{51}$ For that reason, I shall also not discuss a related rhetorical technique, re-definition or re-description, which also plays an important part in legal reasoning (e.g. in precedential reasoning - in the form of redescribing past precedents). For a discussion of this technique, see Skinner 1996, chapter 4. It is also important to note here that the other use of 'colour' is that of a cloaking device - in particular, clothing lies with truth so as to make the former more plausible. As Quentin Skinner explains, Quintilian says 'if you can manage to make your falsehoods cohere with something which is true' you thereby lend 'colour' to your lies: Skinner 2014, p. 253; and see Quintilian 2002, para 4.2.88. Skinner goes on to show how this is deployed by Iago in Othello. In his recent book, From Humanism to Hobbes: Studies in Rhetoric and Politics (2018), Skinner also discusses this practice of colouring (as cloaking lies with truth), showing its close link to the rhetorical figure of paradiastole. For example, this figure is described by Angel Day in 1592 as employed when 'wee color others or our owne faultes': Skinner 2018, p. 101. ${ }^{52}$ In another context, I have drawn on the practice of introducing and exchanging colores to understand the reasoning practices of judges in the common law when they employ hypothetical scenarios: see ch. 8 of Del Mar 2020.
} 
the introduction and exchange of colores, can be understood as a powerful mode of normative inquiry.

How exactly does the introduction and exchange of colores enable and further normative inquiry? It does so because it is on the back of all these colores that we can ask: ought the motivations and intentions that these colores point to (or invite us to infer) be relevant to considering the application of the relevant legal principle to this case and to its consequent implication as to the interpretation of the scope of the legal principle in the future? Declamatory themata often involved duties of sons to fathers and fathers to sons. When introducing and exchanging colores, declaimers and then audiences would offer changes to the narrative that shed light on the possible motivations of sons and fathers, e.g. were the fathers in question motivated by cruelty or kindness, and were the sons motivated by increasing their reputations, eager to show their moral superiority vis-à-vis their fathers, or were they attempting to protect their father's honour? By changing the narrative circumstances, the declaimer and their audience were involved in the communal and interactive tasks of experimenting (especially by regular shifts in perspective and affect) with what norms and values applied to what specific, concrete circumstances.

The introduction and exchange of colores was often accompanied by laughter and joviality. For all that, however, the playfulness of this aspect of declamatory practice was a serious exercise. By introducing and exchanging colores the declaimers were generating possibly relevant norms and values and exploring that relevance in particular circumstances. They were doing so by performing: the colores are not invented in the abstract, but rather in the voice of one of the characters in the thema, and expressed with emotion and gesture. These performances involved emotion and also appealed to the emotion of the audience; and they involved bodies (and senses) directly (e.g. the audience actually hears the outcry or indignation of the characters). Nevertheless, for all the direct affect and kinesis, the communal and interactive dynamics, and thus the generation of multiple colores, the process also reminds the declaimers that they are experimenting, that they are trying out alternatives and possibilities. Along with experiencing the varying colores, the declaimers shift and switch affective allegiance and, at once, evaluative perspective. Their evaluative cognition is on the move they are moved in the sense of emotion and themselves move in the sense of changing evaluative perspective. And, in so doing, they generate and explore what norms and values might be at stake in the relevant domain (e.g. as to relations between fathers and sons).

Speaking specifically of Seneca's colores, Frederick Bonner characterised them in the following way:

By a slight shift of argument, by an added insinuation, or a guileless plea, they tone down the guilt or represent it in even more glaring colours. The colores are the Persian carpet of the declaimer; look at from one angle and the colours are bright and clear, the pattern simple, but observe it from another angle, and the shade deepens, the pattern changes, and the whole appears in a different light. ${ }^{53}$

According to Bonner, prior to Seneca, color was "a general word for "cast" or "tone" or "style"; in Seneca, however, "it takes on the quite different meaning of "twist of argument", "plea", "excuse". ${ }^{54}$ Colores in Seneca, then, are very much part of the argument - they are certainly not dispensable flourishes or mere decoration; they are integral to the practice of advocacy and, more broadly, judgement. In the language of this paper, it is in the fun and pleasurable, even if difficult, process of inventing and exchanging colores that one engages, and learns to engage,

\footnotetext{
${ }^{53}$ Bonner 1949, p. 56.

${ }^{54}$ Ibid. p. 55.
} 
in normative inquiry. The declamatory tradition, and especially the introduction and exchange of colores, enables and furthers normative inquiry because of how it specifically instantiates and combines three features: communality and interactivity, experimentalism and exemplarity.

\section{The Declamatory Tradition in the English Renaissance}

\section{IIA. Declamations in Renaissance Pedagogy and Culture}

Given the importance of colores to the argument of this paper, it will be worth offering a specific example of it in action. Given, further, the emphasis placed in this paper on a declamatory tradition, it makes sense for that example to come from a different historical context. Accordingly, the example I offer in this paper comes from the oeuvre of one of the great English Renaissance legal humanists, Sir Thomas More. Before turning to More, however, it will be helpful to have even a brief sense of the place of the declamations in the Renaissance, especially in England. Here, let me make four points.

First, there is good evidence that the Ancient declamations were read by humanists of the period. Peter Mack, for instance, has noted that copies of the declamations attributed to Quintilian can be found amongst catalogues of book ownership in sixteenth century England. ${ }^{55}$ These were often appended to Quintilian's Institutio Oratoria. Evidence of ownership of Seneca's declamations is harder to find, but according to Neil Rhodes, what was prior to early sixteenth century ${ }^{56}$ a largely negative attitude to the Senecan declamations (at least with respect to their pedagogical value), was reversed upon the publication of Erasmus' collection of them, first published in 1515 and then revised in 1529. Subsequent to 1529, says Rhodes, editions of Seneca contained 'commentary on the declamations by Rudolph Agricola, who had stressed the usefulness of controversiae in his De inventione dialectica' ${ }^{57}$

Second, there is also good evidence that the declamations formed part of the education of boys and young men in English grammar schools and universities. Indeed, as John Wesley has pointed out, English 'Renaissance schools awarded merit almost exclusively in terms of rhetorical performance', their 'halls of learning' being 'full of stirring sounds and sights' ${ }^{58}$ Based upon the statutes of several schools (including Merchant Taylors', Westminster, Norwich and Harrow), Wesley suggests that a typical school day involved students performing seven oral performances in an eight-to-ten hour day. ${ }^{59}$ One of the forms for performance included the declamations. As these were the more advanced forms, their performance 'could occur between one to six times a week, taking up to an hour or more of each day, and it was also an event at which other schools might visit to judge the delivery skills developed elsewhere'. ${ }^{60}$ These were certainly affectively-laden, physical performances. As Wesley notes, 'the sights and sounds of Tudor schools were dominated by the passionate performances of both boys and masters'. ${ }^{61}$ As Neil Rhodes put it, 'we can be confident that this kind of material

\footnotetext{
${ }^{55}$ Mack 2007, fn. 23.

${ }^{56}$ But note: according to Paul Kristeller 'the declamations of the elder Seneca and those attributed to Quintilian began to attract greater attention in the fourteenth century', who adds that 'The textual history of these writings in manuscripts and early printed editions and the commentaries written on them till await further investigation': Kristeller 1979, p. 245.

${ }^{57}$ Rhodes 2008, p. 94.

${ }^{58}$ Wesley 2015, p. 1267.

${ }^{59}$ Ibid.

${ }^{60}$ Ibid.

${ }^{61}$ Ibid. p. 1268.
} 
[the declamations, whether Quintilian or Seneca] formed a vital part of grammar-school education in early modern England'. ${ }^{62}$ Declamations were also present in the period as university exercises. For instance, the university statutes required, as a condition of graduation, that declamations be given: e.g. 'the Oxford statutes of 1549 state that the bachelors of arts must give two declamations before they can graduate as masters'. ${ }^{63}$ There is evidence that the speeches given were in Latin. ${ }^{64}$ It is, then, safe to claim that declamations were part of formal practices of education in Renaissance England. ${ }^{65}$ It is noteworthy that attempts were made to introduce declamations in the Inns of Court, perhaps as part of an overall attempt to classicise the Inns, but the evidence we have suggests that these attempts were unsuccessful. ${ }^{66}$

Third, we also know that the declamatory form was an important model for some literary work in the period. This is especially so with respect to drama, with some plays of the period being directly inspired by declamatory controversiae ${ }^{67}$ If we zoom out further, and understand the declamatory practice in broader terms, as a certain kind of literary play (full of experimentalism and exemplarity) but one devoted in particular to the evaluation of the quality of acts and moral character, then we can see much evidence of such practices in the Renaissance, in and beyond England. ${ }^{68}$ Lawyers or legally-trained humanists certainly played a large role in deploying such literary forms. ${ }^{69}$

Fourth, and finally by way of background historical context, let me note that for the legal scholar, one of the most astounding echoes of the declamatory tradition is in the technical meaning that was given to 'colour' in common law pleading. As described by Donald Sutherland, ${ }^{70}$ this form of pleading involved a defendant (initially in a novel disseisin action, but then in others too) inventing a fictional story in order to force the plaintiff to discuss an issue before the judge, thereby avoiding the matter going before a jury. Thus, for instance, in defending against an action by a plaintiff for wrongful dispossession of some property, the

${ }^{62}$ Rhodes 2008, p. 95.

${ }^{63}$ Mack 2007.

${ }^{64}$ Ibid.

${ }^{65}$ See also Wallace 1936, pp. 34-39.

${ }^{66}$ Samuel Thorne, referring to Edward Waterhous' Commentary on Fortescue (1663), says of it that it 'set out either contemplated changes in the curriculum of the Inns of Court of a plan for a new foundation to take their place. The improvements suggested are notably humanistic: the true pronunciation of the French language is to be introduced; moots are to be argued in good Latin and good French. Three days of each week, during both term and vacation, one of excellent knowledge of the Latin and Greek tongues is to read some orator, or book of rhetoric, openly to all the company... In the mean vacations, after two years passed, instead of moots there are to be daily declamations in Latin, though to this last the happy proviso is added, 'that none of the company shall be bound to be at this'. ... Nothing came of these plans': Thorne 1985, p. 191.

${ }^{67}$ See e.g. Rhodes 2008; Curran 2010; Waith 1988; and Vickers 1970. Peter Mack reports a controversia that has often been taken to have been the source for Shakespeare's The Merchant of Venice: see Mack 2007, p. 135.

${ }^{68}$ The key works in this respect are: Altman 1978; and Trimpi 1983. Indeed, it is these two works that first brought to my attention the importance of the declamatory tradition, especially for the history of both law and literature.

${ }^{69}$ In addition to More, amongst the key figures would be: Montaigne (1533-1592), Sir Philip Sidney (1554-1586), and Sir Francis Bacon (1561-1626). Montaigne was a magistrate; Philip Sidney was educated at the Inns of Court (Gray's Inn); Sir Francis Bacon (also educated at Gray's Inn) was a Lord Chancellor. On Sidney, see further Eden 1986; and Robinson 1968. On Montaigne and Bacon, see Kahn 1995. For further work on Bacon's rhetoric, see Jardine 1974; Vickers 1968; Martin 1992; and Wallace 1943. In terms of More himself, and the variety of his humanist practices, including his deployment of a variety of forms and genres for normative inquiry, e.g. into tyranny, see Wegemer 2011.

${ }^{70}$ Sutherland 1981; see also Landman 2001. 
defendant would invent some entirely fictional story as to why the plaintiff originally sought possession of the property (for instance, because his fictional brother passed it onto him). The plaintiff would then be forced to admit or deny the claim, and thereby to give his or her own version of the basis of his or her claim to the property. There is an echo of the declamation in this pleading practice: one invents a fictional (indeed, the more implausible or unlikely the better) story, and one which places in question the quality of the act, or indeed the character, of the party in the dispute (to which that party must then answer).$^{71}$

\section{IIB. Lucian's Tyrannicide}

Perhaps the best sense, however, of the importance of the declamatory form in the English Renaissance and, at once, an illustration of the relationship between its distinct dynamics of communality and interactivity, experimentalism and exemplarity (especially in terms of colores) and, at once, normative inquiry, is provided by considering More's declamatory exercise. ${ }^{72}$ It can be immediately noted that More's exercise had a communal and interactive dimension: it was proposed by More as a friendly competition between him and his good friend Erasmus. More and Erasmus had been good friends ever since they first met in 1499, and upon Erasmus' second visit to London in 1505 (during which time he stayed with More and his family for 6 months), More proposed that they each both translate Lucian's ${ }^{73}$ declamatory thema Tyrannicide (including the speech Lucian composed on behalf of the character who claims a reward for killing a tyrant) as well as each composing a speech against that claimant. ${ }^{74}$ Lucian's thema is as follows:

A man went to the Acropolis to slay the tyrant. He did not find him, but slew his son and left his sword in the body. When the tyrant came and saw his son already dead, he slew himself with the same sword. The man who went up and slew the tyrant's son claims the reward for slaying the tyrant. ${ }^{75}$

\footnotetext{
${ }^{71}$ This extraordinary echo of the declamatory practice of colores is also picked up on by the drama of the period - drama that can be very closely linked to literary men educated in the Inns of Court. A wonderful account of this dramatic play of colour as a practice of common law pleading is given by Subha Mukherji in her reading of Webster's The White Devil. See Mukherji 2006, chapter 4.

${ }^{72}$ The two sources I rely on for the texts are: Thompson 1939 and 1940, and More 1974.

${ }^{73}$ According to Thompson, Lucian (who was a second-century CE satirist and rhetor, including a ghostwriter for speeches to be used in law courts) was one of the most popular Greek authors of the sixteenth century. Both Erasmus and More were certainly fans - Erasmus, says Thompson, was 'the most paramount Lucianist of his time' $(1939$, p. 856), while More's work (especially his Utopia) is said by many critics to be suffused with a Lucianic spirit (see e.g. McConica 1965, pp. 15-16). Further, More's translations of Lucian's dialogues were in fact the most printed of all his work during his lifetime (more even that of Utopia; More's translations of Lucian's dialogues were printed 13 times during his lifetime, compared with Utopia printed 5-6 times before 1535: see Thompson 1939, p. 857). According to Thompson, Erasmus and More would have shared an enthusiasm for Lucian's irony - indeed, he goes further to suggest that 'Erasmus and More were led to see what might be effected in literature by irony as a result of their common study of Lucian': Thompson 1939, p. 856. It seems that this enthusiasm for Lucian was by no means theirs alone, for their translations were printed 'more than 40 times between 1506 and 1550': Thompson 1939, p. 881. For more on Lucian and declamation, see Guast 2018; and for more on Lucian's life and works, as well as his legacy, see Branham 1989, and Robinson 1979.

${ }^{74}$ See Thompson 1939, p. 866. 'Erasmus tells us on three separate occasions that this proposal [to write a reply] originated with More': see Thompson 1974, p. xxx.

${ }^{75}$ More 1974, p. 197. The version from the 1940 Thompson translation is: 'A man gained entrance to the stronghold of a tyrant, whom he intended to assassinate. He failed to find the tyrant, but killed his
} 
The form of the thema, like the declamations we have considered above, is both experimental and exemplary. The facts are, if not wholly implausible, then still beggar credulity: would a tyrant really take the sword from his son's body and kill himself? How likely is it that a man would leave their own sword in the body of the son? The facts are also exemplary: they call for and require inferential work, being at best only suggestive of possible motives and intentions.

As noted above, in addition to providing the thema, Lucian also composed a speech on behalf of the claimant for the reward. In Lucian's treatment, the claimant presents himself as generous, brave, skilled and full of foresight and planning. He is generous because although he has killed two tyrants, he only claims only one reward. ${ }^{76}$ Further, no one could possibly doubt his bravery (or skill), or also ruthlessness:

I did not draw back when I estimated the difficulty of the achievement, nor play the coward in the face of danger. Alone, alone, I climbed the hill to front the tyranny that was so strong and many-headed... I had my death in prospect, but sought to purchase our common liberty with the shedding of my own blood. I met the first guard-post, routed the guardsmen with little difficulty, slew whomsoever I encountered, destroyed whatsoever blocked my path. Then I assailed the very forefront of my tasks, the sole strength of the tyranny, the cause of our calamities. I came upon the warden of the citadel, I saw him offer a brave defence and hold out against many wounds; and yet I slew him... The tyranny, therefore, had at least been overthrown, my undertaking had attained fulfilment, and from that moment we were all free. Only an old man still remained, unarmed, his guards lost, that might henchmen of his gone, deserted, no longer even worthy of a valiant arm. ${ }^{77}$

Here, the son of the tyrant is clearly characterised as being in the prime of his strength, with the actual tyrant but an old man with no effective power. Indeed, the claimant argues that the tyrant only had 'the name of sovereignty', with actual power being exercised by the son. ${ }^{78}$ The claimant slew the son 'after a hard fight'; ${ }^{79}$ leaving his sword, too, was a calculated move. At every turn, the claimant emphasises his 'will' - to succeed, he says, one had to have 'a will that is valiant, patriotic, disposed to run risks for the common weal, and ready to purchase by its own extinction the deliverance of the people'. ${ }^{80}$ The claimant knew that the tyrant, left alone with a grief for his son that he dearly loved, would kill himself: 'I knew', he says, 'that he would lay down his life at once'. ${ }^{81}$ Indeed, so much does the claimant emphasise his will that he casts himself as the author of the whole affair: 'Before I slipped away, I had myself composed the whole plot of the tragedy, but had left to the actor the body, the stage-setting, the sword, and the remainder of the play'. ${ }^{82}$

More deploys plenty of rhetorical invention - introducing colores to overturn this characterisation, urging us instead to see the claimant as reckless, hapless, with little or no foresight, and very much a coward. This is how More re-tells the story of what happened: ${ }^{83}$

son and left his sword sticking in his body. The tyrant discovered his son's body and killed himself with this same sword. The slayer of the son now claims the reward for tyrannicide': Thompson 1940, p. 13.

${ }^{76}$ More 1974, p. 197.

${ }^{77}$ Ibid. p. 199.

${ }^{78}$ Ibid. p. 198.

${ }^{79}$ Thompson 1940, p. 36.

${ }^{80}$ More 1974, p. 201.

${ }^{81}$ Ibid. p. 203.

${ }^{82}$ Ibid. p. 204.

${ }^{83}$ As summarised by Thompson, Erasmus re-tells the story in this way: 'What actually happened was as follows: By good luck you penetrated the citadel and chanced upon the son, who was alone and 
But after he had rashly broken into the citadel - I know not how - and there suddenly attacked and overpowered the young man, who (with the carelessness of youth) was alone, off guard, not in the least suspicious; and, advancing further, might perhaps have been able to deal with the tyrant in the same manner - at that instant fright took hold of him, fearful as he was lest, already betrayed to the tyrant's retinue by the cry and groans of the dying youth, he would be captured. Already before his eyes were the chains, dungeon, tortures, and a thousand deaths, a thousand punishments. Terrified by this empty fancy, fearful now of every noise, every sound, and at last afraid of his own shadow, suddenly as timid as before he was rash, he rushed from the citadel; he did not even dare to carry his sword with him, for fear his flight would be slowed or, arrested with a sword in his possession, he would be accused of having plotted against the tyrant - at whose death he now returns arrogantly and demands the reward for tyrannicide, as if he had killed him! ${ }^{84}$

Note how differently we are invited to perceive the claimant here, and his character: he is a coward, taking advantage of a 'careless youth' (note here the very different characterisation of the son, but also the description of the scene - not a 'hard fight' but instead a surprise attack), ${ }^{85}$ and full of fear throughout, where every act is not a calculated one (e.g. the leaving of the sword) but one instead marked by terror and almost random in its execution. Throughout, More de-emphasises the agency of the claimant and emphasises, instead, the agency of the gods (this being a popular color used in the Senecan declamations). 'I shall demonstrate', More says, 'by the plainest proofs that this whole affair is due to fortune and divine clemency, with no thanks at all to this man'. ${ }^{86}$ Although More grants that the claimant appears 'to have committed the deed with patriotic motive', ${ }^{87}$ he argues that it was an entirely reckless and irresponsible attempt, which threw 'the entire city into extreme peril, since by foolishly inciting him he made the tyrant more menacing to the citizens and more wary of plots' ${ }^{88}$ Faced with the prospect of killing the tyrant, the claimant 'dared not do because of fear, would not do because of negligence, or could not do because of chance'. ${ }^{89}$ The claimant acted 'recklessly, rashly, without plan, without thought', leaving the essential task (the killing of the tyrant) yet to be done - and yet, he has the effrontery to claim a reward (the claimant is thus not generous but greedy). ${ }^{90}$ It was, again, the gods rather than the claimant, who saved the city:

unguarded and in a drunken slumber. Him you killed. Fearing discovery, you fled, not even pausing long enough to pull your sword from his body. You hid in your home, trembling in terror until, hearing that the tyrant was dead, you suddenly stepped forward with your impossible fiction of being the author of his death and demanded the reward decreed for tyrannicide. You did not kill the tyrant, because you were too afraid to try to do so': Thompson 1940, p. 18. For a translation of most of the Erasmus' text, see Rayment 1959.

${ }^{84}$ More 1974, p. 121.

${ }^{85}$ At one point, More even suggests that a 'keener advocate' than More might argue that 'you climbed to the stronghold not to free your country (which you did not accomplish), not to kill the tyrant (whom you did not touch), but rather to slay the very youth whom you did murder: you did that in revenge or retaliation for some private injury done to you', but then (so as to demonstrate his generosity and grace - construct his own character as an advocate) says that 'I shall not deal with you in this manner, since in matters extremely obscure, like this, I am accustomed always to incline to the more lenient interpretation': More 1974, p. 107.

${ }^{86}$ Ibid. p. 101

${ }^{87}$ Ibid. p. 107.

${ }^{88}$ Ibid. p. 111.

${ }^{89}$ Ibid. p. 115.

${ }^{90}$ Ibid. p. 121. 
After the state had fallen into the gravest anger, first because of this man's rashness, then by his cowardice, the gods, thinking the time had come to fashion for us an everlasting memorial of their favour, suddenly diverted all the calamities pressing so closely on us to the head of the tyrant himself. ${ }^{91}$

More's re-tellings (as well as his omissions and additions, as compared to Lucian's declamation on behalf of the claimant), like the colores introduced by the declaimers in Ancient Rome, use narratological techniques to shift our emotional allegiance, rousing indignation and anger within us (on behalf of the population of the city, and perhaps even on behalf of the tyrant and his son, for whom we might suddenly feel some sympathy), and re-framing our evaluative perception, away from a positive evaluation of the character's act (of slaying a tyrant, and freeing the city), and towards a negative evaluation, which sees the character's act as reckless and irresponsible, risking the safety of the city rather than freeing it. Reading More, we begin to shift our emotional allegiance, away from the claimant, and very much against him - seeing him now as full of fear, and even cruel in unnecessarily killing a son that was vulnerable, and certainly not an agent in control of the future, but very much privy to the winds of fate. It is a complete turn-around - and masterfully done. And it bears very close resemblance to similar rhetorical feats of the student rhetors in Ancient Rome.

As with the Roman declamations, this art may at first blush strike us as mere entertainment - as divorced from the heavy matters of law and politics. But it is not so at all: the question of when and how it may be appropriate to slay a tyrant could be understood as a dramatization of the larger question of the duty of citizens, including the scope of political (dis)obedience, as well as issues of good government. Certainly, the genre of tyranny (including the more specific variant of tyrannicide) was, already by the sixteenth century, a very popular one. ${ }^{92}$ Although, arguably, the relevance of this literature was to achieve a greater prominence in seventeenth century England, one can hardly doubt its attraction, and indeed importance, in any period, let alone as fast-changing a one as the sixteenth century. Issues surrounding tyranny were of course explored in more abstract ways (the work of the Scottish humanist, George Buchanan, 1506-1582, can serve as an illustrious example), ${ }^{93}$ but they were also explored in more indirect ways, precisely in such declamatory exercises as well as of course in the drama of the period. Indeed, my point here is precisely that if, in pursuit of the theory and history of legal and political thought we confine ourselves to abstract texts, like Buchanan's, then we will miss out on large swathes of legal and political thought engaged in via aesthetic practices (as here, in the Erasmus's and More's declamatory exercise).

\footnotetext{
${ }^{91}$ Ibid. p. 123.

92 The literature of tyranny, and the accompanying interest in the despot and description of him, was of course an ancient and extensive one, see e.g. in Plato (Books 8 and 9 of The Republic), Aristotle (Book 5 of Politics), and Luther, Melanchthon, and Calvin. For more on tyranny and law in More's reply to Lucian, see Corral 2012; Ransom 2013; and Logan 2007.

${ }^{93}$ See George Buchanan, On the Law of Kingship Among the Scots (1579), and the reply from King James, Trew Lawe of Free Monarchies (1589). According to Lorna Hutson, 'a developing discourse defining the limits and obligations of the monarch's power (and culminating in the constitutional crises of ship money and the Five Knights Case) is to be found embedded in the procedural writings of those administering justice: that is, with Inns of Court readings, with law reports, both published and unpublished (the most famous of which are by Plowden and Coke), with dialogues and discourses on specific jurisdictions (such as those by Christopher St. German, Edward Hake, and William Lambarde on equity and the common law), and with the way in which all these made their way into administrative handbooks': Hutson 2015, p. 125.
} 
Normative inquiry, or the pursuit of insights into possibly relevant norms and values in this case, at stake in tyranny - could be generated through the combination of communality and interactivity, experimentalism and exemplarity, as exhibited in the declamatory tradition, and especially the introduction and exchange of colores. What is the appropriate course of action open to citizens of a city who, say, are under the formal rule of an aging tyrant, but really under the informal and effective rule of his son? Should a reward for slaying the tyrant extend to his son who has de facto power? Does such an act place the city in too much danger, given the possibility of the tyrant seeking revenge for the death of his son? These and other questions - possible norms and values at stake - are generated by and through the experimentalism and exemplarity of the declamatory form. As noted above, it is also significant for my purposes that Erasmus and More performed this exercise together: clearly, it was, for them, a communal and interactive process - which, given its popularity, was also enjoyed by many audiences. Once again, we see the three features of the declamatory tradition at work in the enabling and furthering of normative inquiry. The fact that the declamatory form was being used suggests that it continued to be useful for lawyers, and humanists more generally, as a form of training and development, much beyond its immediate Ancient context. Indeed, a good argument can be mounted that More not only engaged in declamatory exercises but was also influenced by the declamatory genre in his other literary output. Edward Berry, for instance, argues in the case of More's Utopia, book 2, and thus Hythloday's description of Utopia, is declamatory. ${ }^{94}$ In these further relations we have more proof that, as theorists and historians of legal and political thought, we ignore such aesthetic practices at our peril.

\section{Conclusion}

In this paper, I have offered the declamatory tradition as an example - I would suggest a powerful example - of an aesthetic tradition of normative inquiry. The argument has been that the declamatory tradition enables and furthers such normative inquiry because it is characterised by three features: communality and interactivity; experimentalism; and exemplarity. I have argued, in particular, that the integration of these three features is most visible in one aspect of declamatory practice: the introduction and exchange of colores, i.e. changes in the narrative, introduced by a declaimer and their audience, which shed light on the possible motivation of a character, and thereby also invite shifts in affective allegiance and evaluative perspective. It is, I have suggested, through such introduction and exchange of colores that the declamatory tradition enables and furthers normative inquiry, i.e. exploration of the norms and values that contribute to the good life and the common good. I sought to illustrate this relation between the dynamics of colores and normative inquiry in the particular example of More's response to Lucian's declamatory thema, Tyrannicide.

I hope that this brief investigation into the declamatory tradition may interest others in delving further into this tradition, but also to look more broadly at what are the features of aesthetic practices that enable and further normative inquiry. To do that, and to theorise it historically, is to engage in what we might call an aesthetic history of legal and political thought.

\footnotetext{
${ }^{94}$ Berry 2009, p. 329. Berry also makes connections between declamations and mooting.
} 


\section{References}

Altman, J (1978) Tudor play of mind: rhetorical inquiry and the birth of Elizabethan drama. Berkeley: University of California Press.

Amato E, Citti F, and Huelsenbeck B (eds) (2015) Law and ethics in Greek and Roman declamation. Berlin: De Gruyter.

Bernstein, N (2013) Ethics, identity and community in later Roman declamation. New York: Oxford University Press.

Berry, E (2009) Thomas More and the legal imagination. Studies in Philology 106(3): 316340.

Bloomer, M (2010) Roman declamation: the elder Seneca and Quintilian. In: Dominik and Hall (eds), pp. 297-306.

Bloomer, M (2011) Quintilian on the child as a learning subject. The Classical World 105(1): 109-137.

Bloomer, M (2015) Latinity and Literary Society at Rome. Philadelphia: University of Pennsylvania Press.

Bonner, F (1949) Roman declamation in the late republic and early Empire. Liverpool: Liverpool University Press.

Branham, R.B. (1989) Unruly eloquence: Lucian and the comedy of traditions. Cambridge, MS: Harvard University Press.

Brightbill, J (2015) Roman declamation between creativity and constraints. Available online: https://knowledge.uchicago.edu/record/492.

Connolly, J (2016) Imaginative fiction beyond social and moral norms. In Dinter, Geurin and Martinho (eds), pp. 191-207.

Corbeill, A (2010) Rhetorical education and social reproduction in the Republic and early Empire. In: Dominik and Hall (eds), pp. 69-82.

Corral, H (2012) Thomas More on tyranny and law in Thomas More's declamation in reply to Lucian's Tyrannicide. Moreana 49 (189): 71-88.

Crook, JA (1995) Legal advocacy in the Roman world. London: Duckworth.

Curran, J (2010) Declamation and character in the Fletcher-Massinger plays. Medieval \& Renaissance Drama in England 23: 86-113. 
Del Mar, M (2020) Artefacts of legal inquiry: the value of imagination in adjudication. Oxford: Hart.

Dinter MT, Guerin C, and Martinho M (eds) (2016) Reading Roman declamation: the declamations ascribed to Quintilian. Berlin: De Gruyter.

Dominik W, and Hall J (eds) (2010) A companion to Roman rhetoric, Oxford: Blackwell.

Eden, K (1986) Poetic and legal fiction in the Aristotelian tradition. Princeton: Princeton University Press.

Enders, J (1992) Rhetoric and the origins of medieval drama. Ithaca: Cornell University Press.

Fleming, D (2003) The very idea of a progymnasmata. Rhetoric Review 22(2): 105-120.

Fletcher, A (2016) Comic democracies: from ancient Athens to the American republic. Baltimore: The Johns Hopkins University Press.

Friend, C (1999) Pirates, seducers, wronged heirs, poison cups, cruel husbands, and other calamities: the Roman school declamations and critical pedagogy. Rhetoric Review 17(2): 300320.

Gallagher, C (2018) Telling it like it wasn't: the counterfactual imagination in history and fiction. Chicago: Chicago University Press.

Guast, W (2018) Lucian and declamation. Classical Philology 113: 189-205.

Gunderson, E (2003) Declamation, paternity and Roman identity: authority and the rhetorical self. Cambridge: Cambridge University Press.

Hutson, L (2015) Circumstantial Shakespeare. Oxford: Oxford University Press.

Jardine, L (1974) Francis Bacon: discovery and the art of discourse. Cambridge: Cambridge University Press.

Kahn, V (1995) Rhetoric, prudence and skepticism in the renaissance. Ithaca: Cornell University Press.

Kaster, R (2001) Controlling reason: declamation in rhetorical education at Rome. In Too, YL (ed), Education in Roman Antiquity, Leiden: Brill, pp. 317-337.

Kristeller, P (1979) Renaissance thought and its sources. New York: Columbia University Press.

La Caze, M (2002) The analytic imaginary. Ithaca: Cornell University Press.

Landman, J (2001) Pleading, pragmatism, and permissible hypocrisy: the 'colours' of legal discourse in late medieval England. In: Scase W, Copeland R, and Lawton D (eds), New medieval literatures, vol. 4, Oxford: Oxford University Press, pp 139-170. 
Logan, G (2007) Thomas More on tyranny. Thomas More Studies 2: 19-32.

Lysyk, S (1998) Purple prose: writing, rhetoric and property in the Justinian corpus. Cardozo Studies in Law and Literature 10: 33-60.

Mack, P (2007) Declamations in renaissance England. Papers in Rhetoric 8: 129-155.

Martin, J (1992) Francis Bacon, the state, and the reform of natural philosophy. Cambridge: Cambridge University Press.

McConica, J (1965) English humanists and reformation politics under Henry VIII and Edward VI. New York: Oxford University Press.

Mendelson, M (1994) Declamation, context and controversiality. Rhetoric Review 13(1): 92107.

Miller, HK (1956) The paradoxical encomium with special reference to its vogue in England, 1600-1800. Modern Philology 53(3): 145-178.

More, T (1974), Translations of Lucian. Complete Works. Vol. 3.1. New Haven: Yale University Press.

Mukherji, S (2006) Law and representation in early modern drama. Cambridge: Cambridge University Press.

Parks, P (1946) The Roman rhetorical schools as a preparation for the courts under the early Empire. Baltimore: The Johns Hopkins University Press.

Quintilian (2002) Institutio oratoria. trans. Russell, D. Cambridge, MA: Harvard University Press).

Ransom, E (2013) Opposing tyranny with style: More, Lucian, and classical rhetorical theory. Moreana 50: 159-186.

Rayment, C (1959) The Tyrannicida of Erasmus: translated excerpts with introduction and commentary. Speech Monographs 26(4): 233-247.

Rhodes, N (2008) Shakespeare and the origins of English. Oxford: Oxford University Press.

Robinson, C (1979) Lucian and his influence in Europe. London: Duckworth.

Robinson, P (1968) The shape of things known: Sidney's Apology in its philosophical tradition. Cambridge, MA: Harvard University Press.

Roller, M (1997) Color-blindness: Cicero's death, declamation, and the production of history. Classical philology 92(2): 109-130.

Russell, DA (1983) Greek declamation. Cambridge: Cambridge University Press. 
Seneca, the Elder (1974) The declamations: controversiae. 2 vols. Winterbottom, M (ed). Cambridge, MS: Harvard University Press.

Skinner, Q (1996) Reason and rhetoric in the philosophy of Thomas Hobbes. Cambridge: Cambridge University Press.

Skinner, Q (2014) Forensic Shakespeare. Oxford: Oxford University Press.

Skinner, Q (2018) From humanism to Hobbes: studies in rhetoric and politics. Cambridge: Cambridge University Press.

Sloane, T (1985) Donne, Milton and the end of humanist rhetoric. Berkeley: University of California Press.

Sutherland, D (1981) Legal reasoning in the fourteenth century: the invention of 'color' in pleading. In: Arnold MS, Greene TA, Scully SA, and White SD (eds), On the laws and customs of England: essays in honour of Samuel E Thorne, Chapel Hill: University of North Carolina Press, pp. 182-194.

Thompson, CR (1939) The translations of Lucian by Erasmus and St Thomas More. Revue Belge de Philologie et D’Histoire 18(4): 855-881.

Thompson, CR (1940) The translations of Lucian by Erasmus and St Thomas More continued. Revue Belge de Philologie et D’Histoire 19(1): 5-35.

Thompson, CR (1974) Introduction in More (1974), pp. i-lxxii.

Thorne, S (1985) Essays in English Legal History. London: Hambledon Press.

Trimpi, W (1983) Muses of one mind: the literary analysis of experience and its continuity. Oregon: Wipf \& Stock.

Vickers, B (1968) Bacon and renaissance prose. Cambridge: Cambridge University Press.

Vickers, B (1970) Classical rhetoric in English renaissance poetry. Carbondale: Southern Illinois University Press.

Waith, E (1988) Patterns and perspectives in English renaissance drama. Newark: University of Delaware Press.

Walker, J (2005) Mime, comedy, sophistry: speculations on the origins of rhetoric. Advances in the History of Rhetoric 8(1): 199-209.

Wallace, K (1936) Rhetorical exercises in Tudor education. Quarterly Journal of Speech 22(1): 28-51.

Wallace, K (1943) Francis Bacon on communication and rhetoric. Chapel Hill: University of North Carolina Press. 
Wegemer, G (2011) Young Thomas More and the arts of liberty. Cambridge: Cambridge University Press.

Wesley, J (2015) Rhetorical delivery for renaissance English: voice, gesture, emotion and the sixteenth-century vernacular turn. Renaissance Quarterly 68: 1265-1296.

Wiese, C (2016) Good people declaiming well: Quintilian and the ethics of ethical flexibility. Advances in the History of Rhetoric 19(2): 142-156.

Winterbottom, M (1974) Introduction, in Seneca, the Elder, vol. 1, pp. vii-xxix.

Winterbottom, M (2019) Papers on Quintilian and ancient declamation. Oxford: Oxford University Press. 